\title{
Genetic Diagnosis of Claudin-16 Deficiency and Sex Determination in Bovine Preimplantation Embryos
}

\author{
Hiroki HIRAYAMA ${ }^{1)}$, Soichi KAGEYAMA ${ }^{1)}$, Satoru MORIYASU ${ }^{1)}$, \\ Takashi HIRANO ${ }^{2)}$, Yoshikazu SUGIMOTO ${ }^{2)}$, Naohiko KOBAYASHI ${ }^{3)}$, \\ Mutsumi INABA ${ }^{4)}$, Ken SAWAI ${ }^{1)}$, Sadao ONOE $^{1)}$ and Akira MINAMIHASHI ${ }^{1}$ \\ 1)Hokkaido Animal Research Center, Hokkaido 081-0038, ${ }^{2}$ Shirakawa Institute of Animal \\ Genetics, Japan Livestock Technology Association, Fukushima 961-8061, ${ }^{3)}$ Gifu Prefectural \\ Livestock Research Institute, Gifu 506-0101, and ${ }^{4}$ Laboratory of Molecular Medicine, \\ Graduate School of Veterinary Medicine, Hokkaido University, Hokkaido 060-0818, Japan
}

\begin{abstract}
Renal tubular dysplasia is an autosomal recessively inherited disorder in Japanese black cattle that is due to deletion mutations in the claudin-16 gene and causes chronic renal failure and death of affected animals. Here, we report a multiplex-PCR procedure to determine the genotype for claudin-16 deficiency in preimplantation embryos. The presence or absence of the wild-type and mutant allele(s) was precisely detected with the multiplex-PCR using as little as 5 pg of genomic DNA from leukocytes. When biopsied embryo cells were examined for claudin-16 deficiency, 97.2\% of genotypes were consistent with the PCR results obtained for the corresponding embryos. In addition, sexing of embryos by PCR was performed using an aliquot of DNA extracted from biopsied embryo cells, and determination of claudin-16 genotype and sex was successfully achieved with an efficiency of $91.7 \%$ for claudin-16 genotyping and $83.3 \%$ for sexing. The production of a 100 -day fetus that was male and homozygous for claudin-16 deficiency, as expected from the analysis of biopsied embryo cells, gave evidence of the reliability and applicability of this procedure for preventing the transmission of this disease and for enabling advances in animal breeding.

Key words: Claudin-16, Sexing, Preimplantation genetic diagnosis, Cattle, Embryo
\end{abstract}

(J. Reprod. Dev. 50: 613-618, 2004)

$\mathbf{T}^{\mathrm{b}}$ he combined use of embryo transfer and molecular genetics has greatly improved the efficiency of animal reproduction and breeding. Analyses based on DNA amplification, for example, of nucleotide sequences specific to the sex chromosome are precise and efficient procedures for sexing of preimplantation embryos and have been commonly utilized in commercial embryo production [1-4]. Development of analytical procedures that are sensitive and specific for the detection in embryos of genetic mutations leading

Accepted for publication: July 27, 2004

Correspondence: H. Hirayama, (e-mail: h.hirayama@agri.pref. hokkaido.jp) to inherited disorders [5-8], or of quantitative trait loci for milk and meat production [9-13], will provide advantages for preventing the transmission of genetic disorders and for markerassisted selection of animals for breeding.

Renal tubular dysplasia associated with chronic interstitial nephritis and diffuse zonal fibrosis is a genetic disorder in Japanese black cattle [14, 15]. This autosomal recessive disorder is characterized by atrophic renal tubes and extensive interstitial fibrosis with inflammatory cell infiltration, and leads to death of calves prior to puberty, usually within the first 6 months of life. Recently, a 37-kb deletion mutation encompassing the first four 
exons (Type- 1 mutation) and another $56-\mathrm{kb}$ deletion mutation encompassing exons $1-5$ (Type-2 mutation) of the claudin-16/paracellin-1 (CL-16/ $P C L N-1)$ gene were identified as causative mutations for the disorder, and determination of the CL-16 genotype based on PCR has been reported [6, 7]. These PCR procedures have been utilized for $C L-16$ genotyping of blood sample from calves and adult animals, but analysis of very small amounts of DNA, for example, samples from preimplantation embryos, has not been reported. Determination of the $C L-16$ genotype in embryos makes it possible to select animals free from CL-16 deficiency and to maintain carrier animals as a genetic resource for the improvement of cattle.

In this study, we established an effective procedure for detecting CL-16 wild-type and type- 1 mutant alleles in bovine preimplantation embryos. Furthermore, we attempted to diagnose two characters (CL-16 deficiency and sex) in embryos, and to demonstrate the availability of the procedure by embryo transfer.

\section{Materials and Methods}

\section{Embryo production}

Japanese black cattle were superovulated by administering FSH (20 IU/cow, Antorin ${ }^{\circledR} \mathrm{R} \bullet 10$, Denka Pharmaceutical Co., Ltd., Kanagawa, Japan) twice daily in decreasing doses over 3 days. PGF2 $\alpha$ (cloprostenol $0.5 \mathrm{mg} /$ cow, Resipron ${ }^{\circledR}-\mathrm{C}$, Teikoku Hormone Mfg. Co., Ltd., Tokyo, Japan) was injected on the third day of superovulation. The cows were inseminated $24 \mathrm{~h}$ after the onset of estrus, and their uteri were flushed at 6-7 day after artificial insemination. Cows homozygous for the wild-type allele (Experiment 1) and heterozygous for the type-1 mutant allele (Experiment 2) of the $C L-16$ gene were inseminated with sperm derived from a heterozygous carrier of the $C L-16$ type- 1 mutant allele.

\section{Detection of CL-16 alleles by multiplex-PCR}

Multiplex-PCR was performed using a Multiplex PCR Kit (QIAGEN Inc., Valencia, CA, USA) according to the manufacturer's protocol. The sequences of wild-type specific primers were CLNF; 5'- TGGGAGGAAGTGCACTATGA-3' and CLNR; 5'- ATGAGCCTACTCTGCCCACT-3' (PCR product; $338 \mathrm{bp})$. The sequences of type- 1 mutation specific primers were CLMF; 5'GCAGGAGAGTTTGAGCTTGTTAGT $-3^{\prime}$ and CLMR; 5' - CCCCACCCCCACTCTATAC-3' (PCR product; $84 \mathrm{bp}$ ). The PCR mixture (total volume of $20 \mu \mathrm{l}$ ) contained $2 \mu \mathrm{l}$ of $5 \times$ Q-solution, $0.3 \mu \mathrm{M}$ CLNF and CLNR, $1 \mu \mathrm{M}$ CLMF and CLMR and the template. The reaction conditions consisted of initial denaturing at $95 \mathrm{C}$ for $15 \mathrm{~min}$ followed by 45 cycles of $97 \mathrm{C}$ for $30 \mathrm{sec}, 56 \mathrm{C}$ for $90 \mathrm{sec}$ and $72 \mathrm{C}$ for $30 \mathrm{sec}$. The final extension step was followed by 10 min of incubation at $72 \mathrm{C}$.

\section{Sexing of embryos}

Sexing of embryos was performed as previously described [16]. PCR was performed using a HotStarTaq Master Mix Kit (QIAGEN) according to the manufacturer's protocol. DNA was amplified in a $20 \mu \mathrm{l}$ reaction mixture containing $0.75 \mu \mathrm{M}$ primers and the template. The sequences of the primers were S4b1; 5' CAAGTGCTGCAGAGGATGTGGAG-3' and S4b2; 5'-GAGTGAGATTTCTGGATCATATGGCTACT$3^{\prime}$. The reaction conditions consisted of initial denaturing at $95 \mathrm{C}$ for $15 \mathrm{~min}$ followed by 15 cycles of $97 \mathrm{C}$ for $8 \mathrm{sec}, 50 \mathrm{C}$ for $25 \mathrm{sec}$ and $72 \mathrm{C}$ for $15 \mathrm{sec}$, and 30 cycles of shuttle PCR at $98 \mathrm{C}$ for $8 \mathrm{sec}$ and at $66 \mathrm{C}$ for $20 \mathrm{sec}$. The final extension step was followed by $5 \mathrm{~min}$ of incubation at $72 \mathrm{C}$. A PCR product common to males and females (145 bp) was amplified in the reaction. Furthermore, an additional male-specific PCR product (178 bp) was amplified in the same reaction only when male DNA was used as the template.

\section{Experiment 1: Sensitivity and accuracy of CL-16 genotyping}

Bovine genomic DNA was extracted using QIAamp DNA Mini Kit (QIAGEN) from peripheral blood leukocytes obtained from a cow that had been determined to be a heterozygote for the $C L-16$ type-1 mutant allele by a previously reported method [6]. Amplification of the DNA by the multiplex-PCR was carried out at various concentrations of genomic DNA (1-50 pg per reaction) to estimate the sensitivity of detection of wild-type and type- 1 mutant alleles of the CL-16 gene. Electrophoresis was performed in a $6 \%$ polyacrylamide gel.

In vivo derived embryos were biopsied by cutting or microaspiration using a micromanipulator. Ten to twenty percent of the trophoblast of blastocysts 
and $2-12$ cells (mean \pm SD; $7 \pm 2$ cells) of the morulae were removed by cutting and microaspiration, respectively. Biopsied cells (E-S) and the rest of the cells in corresponding embryos (E-L) were lysed for $10 \mathrm{~min}$ at $37 \mathrm{C}$ in $5 \mu \mathrm{l}$ of 0.1 $\mathrm{mg} / \mathrm{ml}$ proteinase $\mathrm{K}$ (Wako Pure Chemical Industries, Ltd., Osaka, Japan) and 0.5\% Tween 20 (Nacalai Tesque, Inc., Kyoto, Japan) (PK-TW method). Proteinase $\mathrm{K}$ was then deactivated for 10 min at $99 \mathrm{C}$. The CL-16 genotypes of E-S and E-L were determined by the multiplex-PCR.

Experiment 2: Determination of CL-16 genotype and sex in preimplantation embryos

Ten to twenty percent of the trophoblast of in vivo derived blastocysts were biopsied by cutting. Biopsied cells were lysed in $5 \mu$ l of extraction solution by the PK-TW method, and were then subjected to determination of CL-16 genotype and sex. Aliquots, 4 and $1 \mu \mathrm{l}$, of the DNA solutions were used as templates for $C L-16$ genotyping and sexing, respectively. Electrophoresis was performed in 3\% agarose gel.

Manipulated embryos were maintained for $5 \mathrm{~h}$ in IVD-101 medium (Research Institute for the Functional Peptides, Yamagata, Japan) at $39 \mathrm{C}$ under $5 \% \mathrm{CO}_{2}$. Five manipulated embryos that had been judged as homozygous for the CL-16 type-1 mutant allele were transferred into five recipient cows at 7-9 day after estrus. Pregnancy diagnosis was performed using ultrasound at 45 or 46 day after estrus. A pregnant cow was slaughtered by intravenous injection of an overdose of sodium pentobarbital at day 100 , and the fetus was obtained from the uterus. The slaughter procedure was approved by the Animal Care Committee of Hokkaido Animal Research Center. The genomic DNA of leukocytes, liver and skin of the fetus was extracted using QIAamp DNA Mini Kit (QIAGEN), and genotyping of CL-16 and sexing were performed by the above-mentioned procedures.

\section{Statistical analysis}

The statistical significance of differences between values obtained using different biopsy methods or CL-16 genotypes were evaluated by the Chi-square test.

\section{Results}

Experiment 1: Sensitivity and accuracy of CL-16 genotyping

When multiplex-PCR was performed using genomic DNA heterozygous for the type-1 mutation as the template, both the wild-type and mutant alleles were detected. The minimal amount of DNA template required for visualization of amplified products appeared to be $5 \mathrm{pg}$ in a single reaction (Fig. 1).

As shown in Table 1, all PCR amplifications produced detectable amplification products when genomic DNA from biopsied cells (E-S) was used as the template except that no amplification was observed in one of the samples from cells biopsied by cutting. Genotypes of CL-16 alleles determined for E-S cells were consistent with those identified in the rest, i.e., the vast majority, of cells of corresponding embryos (E-L), although one of the samples that was demonstrated to be heterogeneous for $C L-16$ mutation by analysis of the relevant E-L was misjudged as homozygous by analysis of the E-S cells. Thus, both the efficiency of DNA amplification and accuracy of genotype identification based on the coincidence of the results obtained with E-S and E-L cells were estimated to be about $97 \%$. There was no significant difference in these values for cells prepared by different biopsy procedures, and for cells with distinct $C L-16$ genotypes.

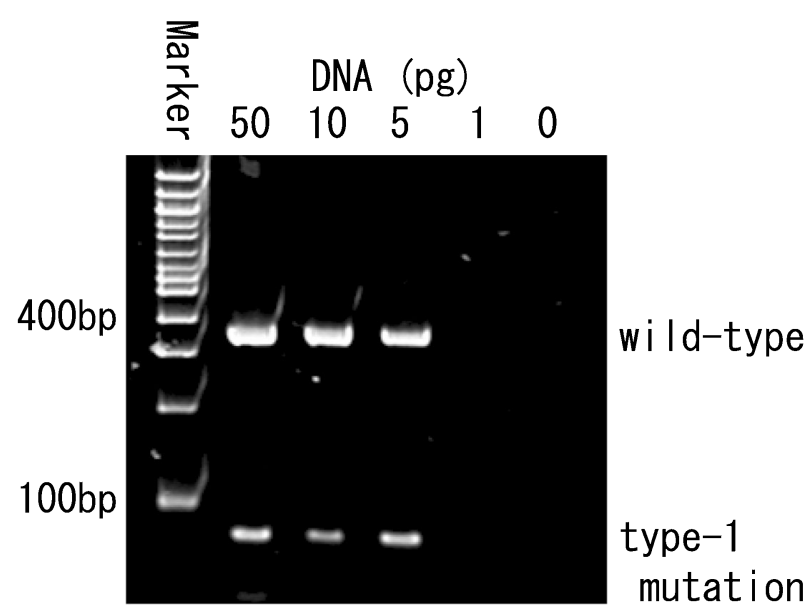

Fig. 1. Sensitivity of detection of $C L-16$ alleles by multiplexPCR. Wild-type and type- 1 mutant alleles were amplified from as little as $5 \mathrm{pg}$ of heterozygous genomic DNA. Electrophoresis was performed in a $6 \%$ polyacrylamide gel. Marker: $100 \mathrm{bp}$ DNA ladder. 
Table 1. Accuracy of $C L-16$ genotyping in bovine embryos

\begin{tabular}{lccccc}
\hline \multirow{2}{*}{$\begin{array}{c}\text { Biopsy } \\
\text { method }\end{array}$} & $\begin{array}{c}C L-16 \\
\text { genotype }\end{array}$ & $\begin{array}{c}\text { No. of } \\
\text { embryos }\end{array}$ & & $\begin{array}{c}\text { No. (\%) with CL-16 } \\
\text { genotype identified }\end{array}$ & $\begin{array}{c}\text { No. (\%) of coincidence } \\
\text { with E-L }\end{array}$ \\
\hline Cutting & wild/wild & 9 & & $8(88.9)$ & $8(100)$ \\
& wild/type- 1 & 9 & & $9(100)$ & $8(88.9)$ \\
Aspiration & wild/wild & 12 & & $12(100)$ & $7(100)$ \\
& wild/type-1 & 7 & & $7(100)$ & $7(100)$ \\
\hline Total & & 37 & & $36(97.3)$ & $35(97.2)$ \\
\hline
\end{tabular}

E-L; biopsied morulae and blastocysts.

E-S; biopsied cells from morulae and blastocysts.

Table 2. Frequency and genotyping efficiency of two analyzed loci in bovine embryos

\begin{tabular}{ccccc}
\hline $\begin{array}{c}\text { No. of } \\
\text { embryos }\end{array}$ & Locus & $\begin{array}{c}\text { Efficiency of } \\
\text { genotyping }(\%)\end{array}$ & Genetic variant & $\begin{array}{c}\text { Frequency of genetic } \\
\text { variant }(\%)\end{array}$ \\
\hline \multirow{3}{*}{12} & \multirow{2}{*}{ CL-16 } & \multirow{2}{*}{$11 / 12(91.7)$} & $\begin{array}{c}\text { wild/wild } \\
\text { wild/type-1 }\end{array}$ & $2 / 11(18.2)$ \\
& & & type-1/type-1 & $5 / 11(36.4)$ \\
\cline { 2 - 5 } & \multirow{2}{*}{ Sex } & \multirow{2}{*}{$10 / 12(83.3)$} & male & $5 / 10(50.0)$ \\
& & & female & $5 / 10(50.0)$ \\
\hline
\end{tabular}

Experiment 2: Determination of CL-16 genotype and sex in preimplantation embryos

As shown in Table 2, the genotyping of CL-16 was successful in 11/12 (91.7\%) embryos, among which 2 embryos (18.2\%) were determined to have wild/wild alleles, 4 embryos $(36.4 \%)$ were determined to have wild/type-1 mutant alleles and the rest $(45.5 \%)$ was determined to have type- 1 mutant/type-1 mutant alleles. Sexing was also successful in embryos at the rate of 10/12 (83.3\%). In 9 out of a total of 12 embryos examined, both $C L$ 16 genotype and sex were accurately determined (Fig. 2).

Five embryos (one male, three females, and one sex-unidentified) homozygous for the CL-16 type-1 mutation were transferred into the uteri of recipients, and one of the recipients was diagnosed as pregnant by ultrasound at day 46. PCR analysis of DNA extracted from leukocytes, liver, and skin of the 100-day fetus demonstrated that the fetus was homozygous for the CL-16 type-1 mutant allele and male, as predicted (Fig. 2).

\section{Discussion}

The procedure using multiplex-PCR in the present study showed high sensitivity and accuracy for the determination of $C L-16$ genotype. First, genotyping of the wild-type and type-1 mutant alleles of the CL-16 gene was achieved in a single reaction using a small amount of DNA as the template. The CL-16 genotype in biopsied embryo samples was precisely determined using this procedure. Although separation of DNA samples into two parts for PCR tests reduces the quantity of template, multiplex-PCR makes improvement of the sensitivity possible by using all templates in a single reaction. In addition, this method of examination gave accurate results for genotyping regardless of the procedure used for biopsy, i.e., cutting versus microaspiration. Cutting of the trophoblast using a microblade is convenient and allows many embryos to be processed in a short time [3]. Biopsy by microaspiration is a suitable technique for obtaining a small number of cells from embryos at stages earlier than the morula, and is useful for reducing the damage caused by the embryo biopsy procedure [1].

To date, several distinct methods have been 

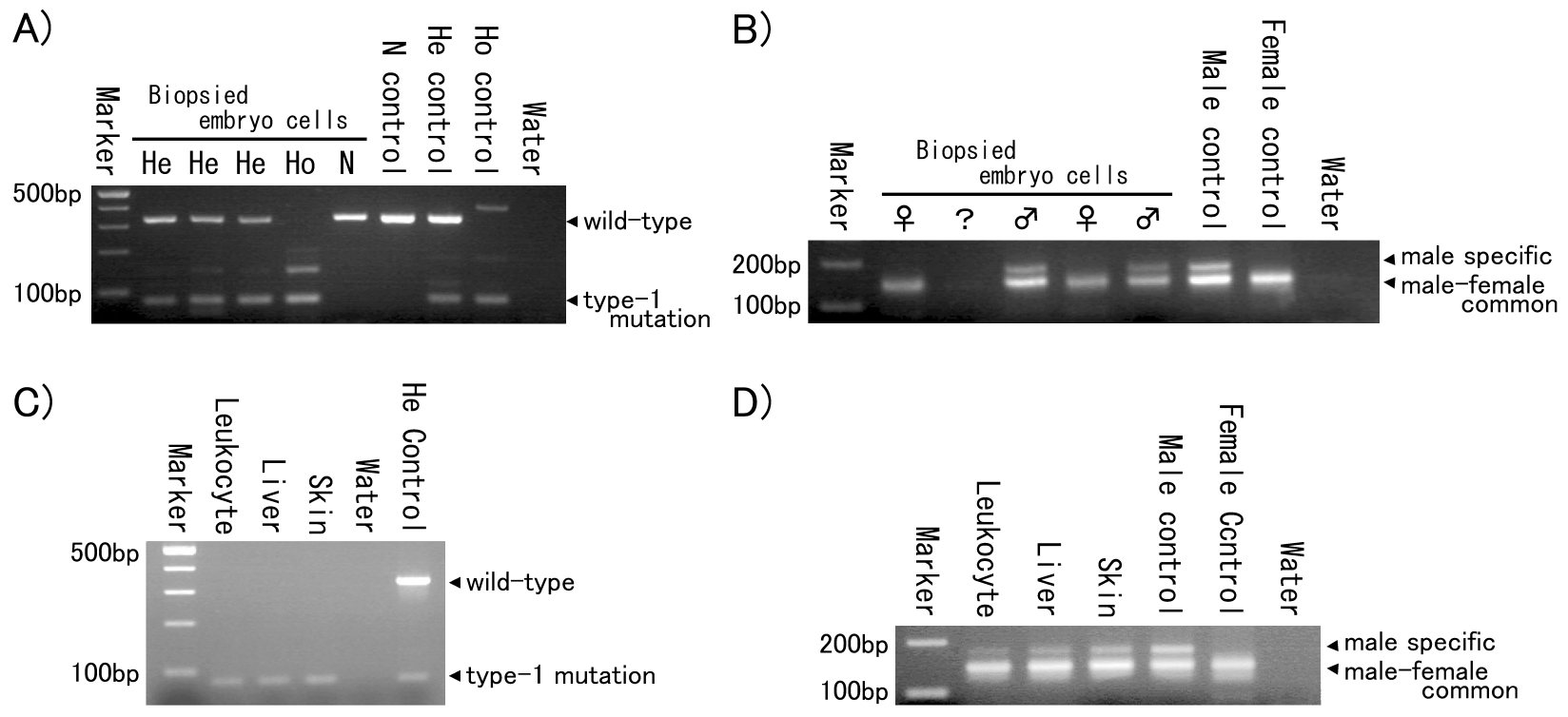

Fig. 2. CL-16 genotyping and sex determination of embryos and a fetus produced from a genetically diagnosed embryo. A) Representative data of $C L-16$ genotyping of biopsied embryo cells. B) Representative data of sex determination of biopsied embryo cells. C) CL-16 genotyping of DNA extracted from leukocytes, liver and skin of a 100-day fetus. All samples were identified as homozygous for the type- 1 mutant allele, as predicted from the analysis of the embryo. D) Sex determination of DNA extracted from leukocytes, liver and skin of a 100-day fetus. All samples were identified as male, as predicted from the analysis of the embryo. He: heterozygous for type- 1 mutant allele. Ho: homozygous for type- 1 mutant allele. N: homozygous for wild-type allele. Marker: $100 \mathrm{bp}$ DNA ladder. Electrophoresis was performed in 3\% agarose gel.

employed to increase the sensitivity of PCR detection using embryo specimens. Preliminary amplification of a small number of copies of a genome is an effective method for obtaining the material for several types of genetic analyses. Primer extension preamplification (PEP)-PCR for amplification of the whole genome from a small number of cells using random oligonucleotides has been used to determine the genotypes in preimplantation embryos $[17,18]$. Nested-PCR is also a suitable method for the detection of trace amounts of DNA from preimplantation embryos [19]. However, these methods have the risk of generating false positives because of DNA contamination during the handling of PCR products in duplicate PCR procedures. Moreover, the application of PEP to samples from a small number of cells is hampered by uncertainties, and amplification artifacts are likely to occur frequently. The multiplex-PCR used in the present study has the additional advantage of eliminating artificial contamination and inadequate amplification in the reaction. The current protocol takes only 5 hours for completion after biopsy. Furthermore, we also performed sex determination using aliquots of the DNA samples. These results indicate that our procedures are useful for rapid and accurate determination of the CL-16 genotype and sex of preimplantation embryos without preliminary amplification.

The generation of a male fetus homozygous for CL-16 deficiency, which had been predicted from the analysis of the embryo prior to embryo transfer, demonstrated the accuracy of the procedures. No obvious morphological abnormality or defect was observed in the fetus (data not shown). Detailed analysis of the fetus will be performed in order to investigate the mechanism of incidence of renal tubular dysplasia in the future.

If high-performance bulls have some mutation(s) causing inherited disorders, it substantially influences the diffusion of the disorders. The selection of carrier animals leads to economic losses and the loss of genetic resources. In our cattle herd, the examinations performed so far indicate that the type-1 mutation is present in the major population of carriers, and the frequency of the type-2 mutation is very low (data not shown). Therefore, 
our procedure to detect the type- 1 mutation will be useful for eliminating the spread of CL-16 deficiency. Furthermore, it will also be useful for maintaining genetic resources and variations of carrier animals without incidence of the disease.
In conclusion, we established the procedure to determine the CL-16 genotype and sex in bovine preimplantation embryos. This procedure can be used for the prevention of genetically caused CL-16 deficiency and the promotion of animal breeding.

\section{References}

1. Thibier $\mathbf{M}, \mathbf{N i b a r t} \mathbf{M}$. The sexing of bovine embryos in the field. Theriogenology 1995; 43: 71-80.

2. Shea BF. Determining the sex of bovine embryos using polymerase chain reaction results: a six-year retrospective study. Theriogenology 1999; 51: 841854.

3. Hasler JF, Cardey E, Stokes JE, Bredbacka P. Nonelectrophoretic PCR-sexing of bovine embryos in a commercial environment. Theriogenology 2002; 58: $1457-1469$.

4. Hirayama H, Kageyama S, Moriyasu S, Sawai K, Onoe S, Takahashi Y, Katagiri S, Toen K, Watanabe K, Notomi T, Yamashina H, Matsuzaki S, Minamihashi A. Rapid sexing of bovine preimplantation embryos using loop-mediated isothermal amplification. Theriogenology 2004; 62: 887-896.

5. Nagahata $\mathbf{H}$, Miura $T$, Tagaki $K$, Ohtake $M$, Noda H, Yasuda T, Nioka K. Prevalence and allele frequency estimation of bovine leukocyte adhesion deficiency (BLAD) in Holstein-Friesian cattle in Japan. J Vet Med Sci 1997; 59: 233-238.

6. Hirano T, Kobayashi N, Itoh T, Takasuga A, Nakamaru T, Hirotsune S, Sugimoto Y. Null mutation of PCLN-1/Claudin-16 results in bovine chronic interstitial nephritis. Genome Res 2000; 10: 659-663.

7. Hirano T, Hirotsune S, Sasaki S, Kikuchi T, Sugimoto Y. A new deletion mutation in bovine Claudin-16 (CL-16) deficiency and diagnosis. Anim Genet 2002; 33: 118-122.

8. Nagahata $\mathbf{H}$, Oota $\mathbf{H}$, Nitanai $A$, Oikawa $\mathbf{S}$, Higuchi $H$, Nakade $T$, Kurosawa $T$, Morita $M$, Ogawa $\mathbf{H}$. Complex vertebral malformation in a stillborn Holstein calf in Japan. J Vet Med Sci 2002; 64: 1107-1112.

9. Georges M, Nielsen D, Mackinnon M, Mishra A, Okimoto R, Pasquino AT, Sargeant LS, Sorensen A, Steele MR, Zhao X, Womack JE, Hoeschele I. Mapping quantitative trait loci controlling milk production in dairy cattle by exploiting progeny testing. Genetics 1995; 139: 907-920.

10. Velmala RJ, Vilkki HJ, Elo KT, de Koning DJ, Maki-Tanila AV. A search for quantitative trait loci for milk production traits on chromosome 6 in Finnish Ayrshire cattle. Anim Genet 1999; 30: 136-143.
11. Riquet J, Coppieters W, Cambisano N, Arranz JJ, Berzi P, Davis SK, Grisart B, Farnir F, Karim L, Mni M, Simon P, Taylor JF, Vanmanshoven $P$, Wagenaar D, Womack JE, Georges M. Finemapping of quantitative trait loci by identity by descent in outbred populations: application to milk production in dairy cattle. Proc Natl Acad Sci USA 1999; 96: 9252-9257.

12. Casas E, Shackelford SD, Keele JW, Koohmaraie M, Smith TPL, Stone RT. Detection of quantitative trait loci for growth and carcass composition in cattle. J Anim Sci 2003; 81: 2976-2983.

13. Kim JJ, Farnir F, Savell J, Taylor JF. Detection of quantitative trait loci for growth and beef carcass fatness traits in a cross between Bos taurus (Angus) and Bos indicus (Brahman) cattle. J Anim Sci 2003; 81: 1933-1942.

14. Kobayashi N, Hirano T, Maruyama S, Matsuno H, Mukoujima K, Morimoto $H$, Noike $H$, Tomimatsu H, Hara K, Itoh T, Imakawa K, Nakayama H, Nakamaru T, Sugimoto Y. Genetic mapping of a locus associated with bovine chronic interstitial nephritis to chromosome 1. Anim Genet 2000; 31: 9195.

15. Michimae Y, Morita T, Sawada M, Shimada A, Akashi S, Sato K, Hikasa Y. A Japanese black calf with claudin-16 deficiency associated with marked loss of the renal tubular epithelium. J Jpn Vet Med Assoc 2003; 56: 798-800 (In Japanese).

16. Kageyama S, Yoshida I, Kawakura K, Chikuni K. A novel repeated sequence located on the bovine $Y$ chromosome: its application to rapid and precise embryo sexing by PCR. J Vet Med Sci 2004; 66: 509514.

17. Garcia JF. Practical considerations of embryo manipulation: preimplantation genetic typing. Theriogenology 2001; 56: 1393-1399.

18. Chrenek $\mathbf{P}$, Boulanger $\mathbf{L}$, Heyman $\mathbf{Y}$, Uhrin $\mathbf{P}$, Laurincik J, Bulla J, Renard JP. Sexing and multiple genotype analysis from a single cell of bovine embryo. Theriogenology 2001; 55: 1071-1081.

19. Apparao KBC, Totey SM. Cloning and sequencing of buffalo male-specific repetitive DNA: sexing of in-vitro developed buffalo embryos using multiplex and nested polymerase chain reaction. Theriogenology 1999; 51: 785-797. 